\title{
Social control and nursing performance in defense of life in the COVID-19 pandemic
}

\author{
Controle social e atuação da enfermagem em defesa da vida na pandemia de COVID-19 \\ Control social y desempeño de enfermería en defensa de la vida en la pandemia del COVID-19
}

'Universidade do Estado do Rio de Janeiro. Rio de Janeiro,

Rio de Janeiro, Brazil.

"Secretaria Municipal de Saúde de Angra dos Reis.

Angra dos Reis, Rio de Janeiro, Brazil.

How to cite this article:

Martins ALX, Crisostomo Jr VJL, David HMSL. Social control and nursing performance in defense of life in the COVID-19

pandemic. Rev Bras Enferm. 2021;74(Suppl 1):e20201310.

https://doi.org/10.1590/0034-7167-2020-1310

Corresponding author:

Amanda de Lucas Xavier Martins

E-mail: amandaxenf@gmail.com

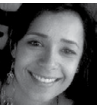

EDITOR IN CHIEF: Dulce Barbosa ASSOCIATE EDITOR: Alexandre Balsanelli

Submission: 12-24-2020 Approval: 04-21-2021

\begin{abstract}
Objective: to reflect on social control in health and the contributions that nursing can make to cope with the COVID-19 pandemic. Methods: this is a theoretical reflection, elaborated from discussions based on literature and the experience of authors' performance in social control and in Primary Care. It is divided into two topics: the first, related to aspects of institutionalized social control; the second, related to the perspectives for nursing in this space. Results: limits and relevant aspects for nurses' role in social control are presented, contributing to a perspective of praxis in health based on their ethical-political commitment and their technical competence in the coordination and management of care to face the pandemic. Final considerations: nurses' role in social control favors the strengthening of the struggle for the right to life above profits, especially through popular participation in the community context in Primary Care. Descriptors: Community Health Nurses; Social Control; Primary Health Care; Nursing; COVID-19.
\end{abstract}

\section{RESUMO}

Objetivo: realizar reflexão acerca do controle social na saúde e as contribuições que a enfermagem pode realizar para enfrentamento da pandemia de COVID-19. Métodos: trata-se de uma reflexão teórica, elaborada a partir de discussões baseadas na literatura e na experiência de atuação dos autores no controle social e na Atenção Básica. Divide-se em dois tópicos: o primeiro, relacionado aos aspectos do controle social institucionalizado; o segundo, relacionado às perspectivas para a enfermagem neste espaço. Resultados: apresentam-se limites e aspectos relevantes para a atuação do enfermeiro no controle social, contribuindo para uma perspectiva de práxis na saúde a partir do seu compromisso ético-político e sua competência técnica na coordenação e gestão do cuidado para enfrentamento da pandemia. Considerações finais: a atuação do enfermeiro no controle social favorece o fortalecimento da luta pelo direito à vida acima dos lucros, especialmente por meio da participação popular no contexto comunitário na Atenção Básica.

Descritores: Enfermagem em Saúde Comunitária; Controle Social; Atenção Primária à Saúde; Enfermagem; COVID-19.

\section{RESUMEN}

Objetivo: reflexionar sobre el control social en salud y los aportes que puede hacer la enfermería para hacer frente a la pandemia del COVID-19. Métodos: es una reflexión teórica, elaborada a partir de discusiones basadas en la literatura y la experiencia del desempeño de los autores en el control social y en Atención Primaria. Se divide en dos temas: el primero, relacionado con aspectos del control social institucionalizado; el segundo, relacionado con las perspectivas de la enfermería en este espacio. Resultados: se presentan límites y aspectos relevantes al rol de enfermero en el control social, contribuyendo a una perspectiva de la praxis de la salud basada en su compromiso ético-político y su competencia técnica en la coordinación y gestión de la atención para enfrentar la pandemia. Consideraciones finales: el rol de las enfermeras en el control social favorece el fortalecimiento de la lucha por el derecho a la vida por encima de las ganancias, especialmente a través de la participación popular en el contexto comunitario en Atención Primaria.

Descriptores: Enfermería en Salud Comunitaria; Control Social; Atención Primaria de Salud; Enfermería; COVID-19. 


\section{INTRODUCTION}

The epidemic of the new coronavirus (COVID-19) was considered one of the most challenging health problems in 2020, due to its rapid and high potential for dissemination and the capacity of health systems to respond to severe cases of the disease, with a strong impact on global public health. Faced with the serious health situation, countries around the world have been confronted with the possibilities of action to contain the spread and assistance to the disease caused by the new coronavirus. In the year of commemoration of the $200^{\text {th }}$ anniversary of nursing, we have observed the importance of nursing role in facing this crisis. The capacity of its workforce involves everything from direct assistance to management, teaching and research for comprehensive health care for individuals, families and communities during the pandemic ${ }^{(1)}$.

In Brazil, since the declaration of Public Health Emergency of National Concern for human infection by COVID-19, in February 2020, efforts have been made to face the pandemic, especially with regard to the organization of flows and availability of beds hospital ${ }^{(1)}$. The Brazilian National Health Council (CNS - Conselho Nacional de Saúde) called for the mobilization of health and society counselors around the commitment to defend the Brazilian Unified Health System (SUS - Sistema Único de Saúde) and guarantee population's right to health. CNS can act by inspecting and monitoring actions to combat COVID-19 in the respective locations, based on science and the highest degree of solidarity to overcome the pandemic. It is important to highlight that social control does not end in the space of councils and conferences, being an important resource to assert the right to health. However, its limitation to institutional actions tends to restrict the potential for action.

The concept of social control may refer to the idea of State control over the population, but, on the other hand, it also means a movement to establish a praxis that contributes to popular participation and civil society action on the State in the management of politics public ${ }^{(2)}$. One should not lose sight of the fact that social control in health is carried out in the contradictory institutional space of a capitalist State ${ }^{(2-3)}$. Nevertheless, it is an important space of dispute and political struggle for meeting the social health demands and needs of public health system professionals and users ${ }^{(2)}$.

From this perspective, institutionalized social control, through health councils and conferences, is a fundamental resource for strengthening SUS and protecting population's health in coping with the serious health crisis of COVID-19. Institutional dispute in health councils can promote democratization in political decisions related to system organization.

The work of health counselors and counselors, combined with the work of surveillance, is essential not only to understand the dynamics of the epidemic in the localities, but also to be able to go further. On the one hand, it favors the promotion of popular participation in decisions and formulation of strategies to face the pandemic, according to the reality of the respective territories and decentralized health services. On the other hand, it promotes the monitoring and inspection of measures taken by the public administration and health management, having as a horizon "life above profits"(2).
It is worth mentioning that nursing has a recognized management capacity in the various health care spaces; when guided by an ethical-political commitment to defend life and involved in the processes of popular participation and social control of public policies, it tends to contribute substantially. It contributes not only to the dispute for the formulation, planning and democratic execution of health interventions, but also to the strengthening of workers' and users' struggle to guarantee integrality and the universal right to health ${ }^{(4)}$.

Moreover, the importance that nursing has been representing in the consolidation of SUS is undeniable. As the largest category in health, in addition to occupying fundamental positions for assistance in the care network, it is present in strategic spaces for the defense of the right to health, as well as in the social control of public health policies. The development of nursing in Brazil follows pari passu with that of SUS, in which its knowledge and interventions are directed not only to individual care, but to collective health, strengthening the identification of needs and the coordination of population's health care. The greatest locus of recognition of nurses' performance in SUS is in the field of public health, with their participation in Primary Care, through the Family Health Strategy, fundamental for the consolidation of public health policies, meeting population's health needs $s^{(5)}$. Furthermore, it is in Primary Care that the greatest power of popular participation and democracy through social control in SUS resides.

In this way, some questions are important to think about the limits and potentialities of action from this space: how can social control contribute to face the pandemic? What are the limits and potential of the performance of institutionalized social control? How can nursing strengthen social control and popular participation to face the pandemic from Primary Care?

\section{OBJECTIVE}

To reflect on social control in health and the contributions that nursing can make to cope with the COVID-19 pandemic.

\section{METHODS}

This is a reflective study, based on critical theoretical foundations ${ }^{(2-3)}$, on popular participation and social control in health and the participation of nursing in this trench of struggle in defense of the right to health of users and health professionals. The article is organized in two main sections, which seek to articulate the theoretical reflection related to the limits and potential of social control in SUS to the trajectory of nursing participation in these spaces, highlighting the potency of their contributions, especially in the wake of the COVID-19 pandemic. This reflection was carried out from the practical experience of nurses working within the Municipal Health Council and in Primary Care, in dialogue with professors from a state university, followed by a survey of the main theoretical frameworks on the subject to deepen the discussion on participation of nursing in social control spaces. Furthermore, a survey was carried out of the main documents related to the positioning of the last Brazilian National Health Conference in the face of attacks against SUS, and CNS, to face the serious health crisis 
caused by the new coronavirus. We emphasize that the discussion on the participation of nursing in the social control space of SUS is linked to its ethical-political and technical competence to dynamize care processes based on popular participation to expand access and defend the universal right to health.

\section{RESULTS}

\section{Social control in the Brazilian Unified Health System and coping with the coronavirus pandemic}

Health conferences and councils are the main democratic spaces, institutionalized by Organic Health Law 8,142/1990, legitimizing social participation in the formulation, planning and inspection of Brazilian public health policy, both taking place at the three levels of government. The latter are composed, evenly, by representations of organized civil society (managers/service providers, workers, and users), being an important institutional space for the fight in the defense of health. They contribute to the participatory management of health policies, in the inspection and formulation of guidelines for health actions ${ }^{(3)}$.

The legal achievement of social control within the health system corresponds to the culmination of struggles during the period of redemocratization of Brazilian society, materializing an expressive set of experiences and reflections on collective health, Popular Health Movements and the Brazilian health reform movement, which had on its horizon the popular struggle for the right to health. Community participation, as an experience of several community medicine projects in Brazil between the 1970s and 1980s, was developed through the use of critical political pedagogical references and from the incorporation of the population in planning and decision in health services in the extension of care in this area to communities ${ }^{(3)}$.

The popular character of participation in social control suffered undisputed losses from its institutionalization, at the height of the Brazilian neoliberal conjuncture in the 1990s, either due to its shift in participation restricted to institutionality, based on councils and conferences, or due to the contradictory character of a capitalist state in the incorporation of class interests ${ }^{(3,6)}$. Moreover, countless contradictions have accumulated in the process of consolidating social control at the institutional level, whether due to difficulties in the process of calling and forwarding proposals at health conferences, or even by evaluations of health status restricted to the elaboration of technical groups from the Ministry of Health, turning the conferences into spaces to legitimize the implementation of SUS; or even by the difficulties inherent in representative bourgeois democracy within the scope of health councils, in liberal terms of the political dynamics of "coalition presidentialism", clientelism and corruption, which erode participation in the elaboration of health policy, privileging the inspection of services and management by counselors; or in critical terms of the concrete conditions of the correlation of working class forces in the face of social inequalities, the restrictions on health financing, with the capture of the public fund by capital and uncertainty regarding the guarantee of universal access to the right to health ${ }^{(6)}$.

The councils and conferences, although they are perceived as spaces for debates and consensus in the disputes of interests between the fractions that compose them, express, in their concreteness, a tendency to reproduce, predominance and legitimization of unilateral management decisions, i.e., to reproduce the current $\operatorname{order}^{(2-3)}$. However, overcoming this inflection of institutionalized social control does not dispense with this space, but it is based on its occupation and criticism that the limits of its form, role and autonomy in relation to the interests of health system professionals and users can be identified, locating the true center of power in the definitions of health policy, whatever the financing is really decided and the role of the pharmaceutical industry and the medical industrial complex realized in the capitalist state ${ }^{(3)}$.

However, even with all the limits of institutionalized participation in health councils, it cannot be overlooked that, in the breaches of their contradictions and limits, achievements can be made for the working class. In this sense, the correlation of forces, at each juncture, is decisive for advances towards meeting population's health needs, even in conditions of fragility for the working class as a whole. As in the current situation of the COVID-19 pandemic, which we can consider a problem situation, for which there is no immediate or constructed response, we can produce the unprecedented-viable from the health crisis.

The presence of organized movements of the working class (associations, movements, professionals, forums, etc.) is fundamental for the promotion of initiatives that have as a horizon the defense of the universal right to health. We would say that the very participation of segments of the working class committed to transforming praxis in defense of life could widen the margins of contradictory gaps and increase the possibilities of strengthening the correlation of forces in their favor.

Just five months before the start of the pandemic, the $16^{\text {th }}$ Brazilian National Health Conference was held, in an already difficult context of attacks and setbacks in health. Among these, we highlight the approval of entry of Foreign Capital in SUS in 2015, the freezing of health and education financing for 20 years in the Constitutional Amendment no 95 of 2016, the new Brazilian National Policy of Primary Care of 2017, the proposal of Agency for the Development of Primary Health Care (Agência de Desenvolvimento da Atenção Primária à Saúde) and the Doctors for Brazil Program (Programa Médicos pelo Brasil) in 2019. Such attacks and setbacks have intensified the dismantling of the Brazilian health and social protection system, especially since the 2016 institutional coup and 2018 presidential election ${ }^{(7)}$.

Nevertheless, the $16^{\text {th }}$ Brazilian National Health Conference, " $8^{a}+8$ Saúde é Democracia", named in honor of the historic $8^{\text {th }}$ Conference, brought together several movements in health as a strategy to convene fighters to build a resistance movement and day of struggles in defense of democracy, social rights and health. In a fierce game of ideological dispute, the $16^{\text {th }}$ was a space for the reaffirmation of SUS as an emancipatory project, despite insistent liberal attempts to disseminate privatizing ideas, more or less hidden ${ }^{(8)}$. However, the counter-reformist avalanche of the current government demanded and continues to demand more strength than the conference can add to the necessary confrontation with SUS dismantling project, already weakened by the serious de-financing since 2016 .

The pandemic has aggravated the scenario of Brazilian political and economic crisis in recent years, urging collective health 
organizations, scientific health societies, professional associations and CNS to constantly stand in defense of health as a fundamental human right and of measures to protect the population and to tackle COVID-19. From the declaration of Public Health Emergency of National Concern, several documents (notes, recommendations, etc.) guiding, in relation to the participation of counselors and technical guidelines, were carried out to subsidize and strengthen social control in the localities, contributing for the performance of users, workers and managers to face the pandemic.

Among the various aspects raised by the "Documento Orientador para Conselhos Estaduais, Municipais e Distrital de Saúde sobre Novo Coronavirus (Covid-19)", of April 1,2020, CNS calls for the mobilization of social control actors to act directly in defense of SUS, stressing the importance of coordinated and integrated actions to face the pandemic in Brazilian territory, in addition to the necessary preparation of health councils to exercise their role during and post-pandemic ${ }^{(9)}$. Although CNS guidelines and positions are fundamental, it should be noted that the strength of its initiatives lies, above all, in the struggle of councilors, organizations and social movements, but, mainly, in the mobilization and struggle of the population in different opportunities, both for social protection and health as a right as well as in the exercise of social control of public health policies.

In this perspective, the appropriation of these mechanisms for the democratization of public health policy management by nursing professionals favors the fight to defend the lives of users and SUS workers themselves at different levels of performance, either in the strengthening of civil/popular health surveillance in the scope of territories, through the attribute of community orientation of Primary Care, and/or in the institutional spaces of councils and conferences in health.

\section{Nursing in social control to face the pandemic and defend the Brazilian Unified Health System}

In nursing, the consolidation of SUS implied the need for professional practice aimed at actions to promote and protect health on a collective basis in Primary Care. The practice of nurses in Family Health is related to aspects of social interaction, such as the promotion and participation in collective activities that engage the community. This interaction can create the basis for a dialogue aimed at reflecting on the society in which we live, through creative and more critical interventions related to quality of life and health conditions. In this sense, nursing is also understood as a social practice and with values that affirm an ethical and political commitment to human emancipation and social transformation. Therefore, the importance of nursing work in Primary Care is on the agenda, which can effectively contribute to a substantial change in the objective conditions of life, which, of course, involves the role of mobilization and popular education to mediate the construction of knowledge and support to the population's social health demands and needs $s^{(5,10)}$.

However, it can be said that the large mass of nursing workers is still far from their greatest potential for action in the pandemic, which may be the educational and mobilizing action, in the exercise of their ethical-political competence ${ }^{(10)}$. In this way, one can directly participate in the processes of building critical awareness that seeks action in defense of life, social protection and the universal right to health for the working class. This includes the struggle for adequate working conditions for professionals in the category and the defense of social protection for health system users $^{(10)}$. In this same perspective, there is an incipient participation of nursing in institutionalized spaces of social control in SUS.

On the other hand, it was not expected that the category would come to act less actively in tackling the pandemic on all fronts of assistance, even under the most difficult and perverse conditions for users and professionals. These conditions were manifested in several challenges in the structure and organization of the care network, such as the number of beds in an Intensive Care Unit (ICU), the quantitative and the qualitative number of health professionals to assist moderate, severe and mild cases, the availability of Personal Protective Equipment (PPE) and COVID-19 diagnostic testing exams, care flows and measures to contain the pandemic ${ }^{(10)}$.

For us in nursing, the struggle for SUS takes place in an undeniable way in juggling, to circumvent the difficulties in assisting users in the daily work process in the different places of care production. Although this struggle is observable, more or less conscious at the level of micropolitics, it is not common to observe the participation of the category in the institutional spaces of dispute and political deliberation. However, paradoxically, we suffer from the neglect of the public health system with users we assist.

We are a fundamental category in enabling users' access to the health system, however one of those that suffer most from the excessive workload in the workday, intensification and precarious working conditions. In the year of commemoration of the 200 years of nursing, we are faced, in fact, with the seriousness of nursing devaluation in Brazilian society; we do not even have the national minimum wage and a 30-hour working day established and regulated. In this sense, the profession is also deeply marked by the social determinations of gender, race and social class. This determination indicates the difficulty in maintaining the reproduction of their own workforce and the engagement of professionals in social control activities that are developed on a voluntary, unpaid basis and outside contractual working hours.

Despite some movements related to the consolidation of nurses' social practice, there are still many challenges for the political strengthening of the professional category and its effective insertion in the discussion of health from a democratic perspective. In general, there is little involvement of nurses in the debates on participation in movements related to the dispute for social projects. There are few initiatives to encourage popular participation by aggregating the community in the construction of collective health political projects that advance the composition of forces capable of mobilizing social transformations.

On the other hand, nurses'knowledge about the management, care coordination and surveillance processes in public health represents great contributions in discussions about the system's operation. Their experience in the management of policies and care favors assertiveness in deliberations, in addition to training user advisers on complex legislation and technical health issues. Especially in pandemic times, the technical knowledge of health surveillance, combined with the potential of community actions in Primary Care, the educational dimension and the coordination of care, inherent to the profession, may come to conform the necessary role for nurses who choose to active political participation in tackling COVID-19. Furthermore, they give visibility to both 
demands and decent working conditions within the scope of SUS.

In the social control of SUS, the participation of nurses often occurs in compliance with a request and/or formal determination of health management, a fact that is explained by the positions of coordination of public health policies and/or programs. Regarding their participation as a representative health worker, although unusual, it occurs through conscious choice of political action to achieve improvements in working conditions on the one hand and, on the other, in the pedagogical action to strengthen users in the fight for the guarantee of the right to health.

It is essential to recognize that the training of nursing professionals still needs to deepen and consolidate their bases in relation to the theme of social control and participation in health. Unfortunately, we still observe the preponderance of nursing education focused on the biomedical area and scientific administration, with reinforcement to the technocratic contours in the management of health policies and little emphasis on their strategic and democratic dimension. That is, training that does not give due relevance to the themes of popular participation in the processes of formulation, decision and deliberation according to the social needs in health, ways and contexts of life of the population.

In summary, the set of contradictions, limits and potentialities for the political performance of nursing in social control spaces points to the need for a reconfiguration not only of practices, but also of their ethical-political bases. It is necessary to produce the self-recognition of the category as a working class, maintaining the fundamental humanistic values, updated to face the complex challenges and pitfalls created by the current devices in the service of capitalist accumulation.

\section{Study limitations}

This article does not aim to exhaust the reflection of the participation of nursing in health councils and conferences, but to incite reflections on the limits, but mainly the potentialities of the occupation of spaces of social control and the exercise of the ethical-political competence of nursing as triggers care processes that focus on popular participation, the defense of the right to health and SUS. These issues become relevant as we experience major setbacks in democratic conquests in Brazilian society, with even more serious contours at the pandemic time, but which need to be the subject of greater theoretical debates and deepening by the category.

\section{Contributions to nursing and public health}

With this reflection, it is expected to contribute to bring to the scene the importance of this theme for the professional performance of nursing, especially considering the dismantling of SUS and its serious impacts on the population and on nursing in the front line in facing the pandemic. In this sense, it is understood that this reflection can encourage nursing professionals, especially in the scope of Primary Care and health councils, to put it into action their ethical-political and technical competences in the mobilization and struggle in defense of the universal right to health to face the pandemic.

\section{FINAL CONSIDERATIONS}

Social control in health is one of the most advanced achievements for the public health system in Brazil, considering the richness of the proposal for decentralization and democratization of decision-making processes related to the organization of services and the protection of population's health. Although under the constraints and limits inherent to bourgeois democracy and its organizational dynamics within the capitalist state apparatus, it is not a space that should be left aside because it represents an arena of disputes between antagonistic interests, which can contribute to favor the correlation of forces for the working class, users and health professionals in the fight for the defense of life, social protection and access to health in midst of a difficult scenario of the pandemic.

Although the role of nursing in institutional spaces for social control is timid, its presence in the primary care services is an important vector of possibilities for effective coping with the COVID-19 pandemic, especially due to the capacity of its workforce to act through popular education, providing opportunities for broadening population's health awareness and mobilization in defense of their health and social rights. Furthermore, when the category is involved in health councils and conferences, driven by a commitment to the defense of population's life, it tends to contribute significantly to the advancement of guidelines for coping with the pandemic, considering their recognized competencies in the scope of coordination and management of health care.

It is necessary to rescue the role of collective health in the practice of nursing, revealing its commitment to the defense of public policies and social justice to protect population's health. Also, it seems to us to be essential to strengthen the role of the category in critical popular educative action, with shared construction of knowledge among users and the ethical-political character of its action to fight for the universal right to health and "life above profits". This thought is especially important in this scenario of a serious health crisis, and may contribute to the State's choices and measures for social protection and guaranteeing access to quality public services by our SUS. In these terms, social control, one of the main mechanisms for this level of coping with the pandemic, can effectively have the possibility of comprehensive, equitable and decentralized care, according to the health needs and ways of life of the groups, addressing the COVID-19 pandemic impacts.

\section{REFERENCES}

1. Ministério da Saúde (BR). Portaria MS/GM n. 188, de 3 de fevereiro de 2020. Declara Emergência em Saúde Pública de importância Nacional (ESPIN) em decorrência da Infecção Humana pelo novo Coronavírus (2019-nCoV)[Internet]. Diário Oficial da União. 2020 [cited 2020 Dec 4]. Available from: https://www.in.gov.br/web/dou/-/portaria-n-188-de-3-de-fevereiro-de-2020-241408388

2. Correia MVC. Que controle social? os conselhos de saúde como instrumento. Rio de Janeiro: Editora Fiocruz; 2003. 164 p. 
3. Stotz EN. Trajetória, limites e desafios do controle social do SUS. Saúde Debate[Internet]. 2006 [cited 2020 Dec 4];30(73-74):149-60. Available from: https://www.redalyc.org/pdf/4063/406345309003.pdf

4. Ponte HMS, Silva AVJG, Pinto FRM, Aguiar FAR, Aviz ALM, Aires SF. Ser enfermeiro, ser conselheiro: despertando para o controle social e saúde pública. Rev Bras Enferm. 2019;72(1):134-9. https://doi.org/10.1590/0034-7167-2017-0544.

5. Backes DS, Backes MS, Erdmann AL, Büscher A. O papel profissional do enfermeiro no Sistema Único de Saúde: da saúde comunitária à estratégia de saúde da família. Ciênc Saúde Colet. 2012;17(1):223-30. https://doi.org/10.1590/S1413-81232012000100024

6. Stotz EN. Educação Popular e Saúde e democracia no Brasil. Interface (Botucatu). 2014;18(Suppl2):1475-86. https://doi. org/10.1590/1807-57622013.0464

7. Giovanella L, Franco CM, Almeida PF. Política Nacional de Atenção Básica: para onde vamos? Ciênc Saúde Colet. 2020;25(4):1475-82. https:// doi.org/10.1590/1413-81232020254.01842020

8. Bispo Jr J, Morais MB. Democracia e Saúde: reflexões e desafios frente à 16a Conferência Nacional de Saúde. Rev Saúde Pública. $2020 ; 54: 16$. https://doi.org/10.11606/s1518-8787.2020054001713

9. Ministério da Saúde (BR), Conselho Nacional de Saúde. Documento Orientador para Conselhos Estaduais, Municipais e Distrital de Saúde sobre Novo Coronavírus (Covid-19)[Internet]. 2020[cited 2020 Dec 4]. Available from: http://www.susconecta.org.br/wp-content/ uploads/2020/04/Documento_Orientador_CNS-covid-REVISADO-1.pdf

10. David HMSL, Acioli S, Silva MRF, Bonetti OP, Passos H. Pandemia, conjunturas de crise e prática profissional: qual o papel da enfermagem diante da Covid-19? Rev Gaúcha Enferm. 2020;42(spe):e20200254. https://doi.org/10.1590/1983-1447.2021.20190254 